\title{
Ketahanan Sistemik Terinduksi pada Tanaman Padi dengan Ekstrak Tumbuhan terhadap Nematoda Bengkak Akar (Meloidogyne graminicola Golden and Birchfiels)
}

\author{
Toto Sunarto ${ }^{1}$, Tarkus Suganda ${ }^{1}$, Martua Suhunan Sianipar ${ }^{1}$ dan Aep Wawan Irwan ${ }^{2}$ \\ ${ }^{1}$ Departemen Hama dan Penyakit Tumbuhan, Fakultas Pertanian, Universitas Padjadjaran \\ ${ }^{2}$ Departemen Budidaya Pertanian, Fakultas Pertanian, Universitas Padjadjaran \\ *Alamat korespondensi: toto.sunarto@unpad.ac.id
}

\begin{abstract}
Induced systemic resistance in rice plant with plant extract to rice root-knot nematode (Meloidogyne graminicola Golden and Birchfiels)
\end{abstract}

Rice is one of important crop that constantly infected by various pathogens. Root-knot nematodes (Meloidogyne graminicola) can decrease rice productivity in Southeast Asia. These nematodes have been reported in Indonesia. Currently nematode control is focused on biological control, application of organic and inorganic materials, natural nematicide, and induction of resistance. The study was conducted in the greenhouse Department of Plant Pest and Disease, Faculty of Agriculture, Universitas Padjadjaran. The purpose of this study was to obtain an effective type of plant extract as an inducer of rice plant resistance to $M$. graminicola. The experiment used experimental method with Randomized Block Design consisting of 6 treatments and 4 replications. The treatment consists of application of plant leaf extract: kirinyuh (Chromolaena odorata), beluntas (Plucea indica), water hyacinth (Eichornia crassipes), spinach thorn (Amaranthus spinosus), control (without plant extract), and carbofuran. The experimental results showed that the extract of beluntas $(P$. indica) and spinach thorn $(A$. spinosus) can decrease the amount of gall on the roots of rice plants, and can suppress the amount of juvenile II $M$. graminicola in $100 \mathrm{ml}$ of soil.

Keywords: Induced systemic resistance, Meloidogyne graminicola, Plant extract, Rice

\begin{abstract}
ABSTRAK
Tanaman padi merupakan tanaman serealia penting di dunia. Patogen tanaman seperti jamur, bakteri, virus, dan nematoda merupakan faktor pembatas pada budidaya tanaman padi. Nematoda bengkak akar (Meloidogyne graminicola) dapat menurunkan produktivitas padi di Asia Tenggara, dan nematoda ini telah dilaporkan terdapat di Indonesia. Pengendalian nematoda parasit tanaman sangat sulit, umumnya menggunakan nematisida kimia yang berbahaya bagi manusia dan lingkungan. Saat ini pengendalian nematoda difokuskan pada pengendalian secara biologi, aplikasi bahan organik dan inorganik, nematisida alami, dan induksi resistensi. Penelitian ini dilakukan di rumah kaca Departemen Hama dan Penyakit Tumbuhan, Fakultas Pertanian Universitas Padjadjaran, Jatinangor. Tujuan penelitian adalah untuk memperoleh jenis ekstrak tumbuhan yang efektif sebagai bahan penginduksi ketahanan tanaman padi terhadap $M$. graminicola. Penelitian menggunakan metode percobaan dengan Rancangan Acak Kelompok terdiri dari 6 perlakuan dan 4 ulangan. Perlakuan terdiri dari kontrol (tanpa ekstrak tumbuhan), aplikasi ekstrak daun tumbuhan kirinyuh, beluntas, eceng gondok, bayam duri, dan karbofuran. fek ekstrak tumbuhan sebagai bahan penginduksi tanaman diuji terhadap jumlah gall pada akar, jumlah juvenile tingkat kedua (J2) M. graminicola dalam tanah, berat basah bagian atas tanaman, berat basah akar, dan tinggi tanaman padi. Hasil percobaan menunjukkan bahwa aplikasi ekstrak daun tanaman bayam duri dan beluntas dengan metode seed treatment (perendaman benih padi) dan soil drench (penyiraman pada tanah sekitar tanaman padi) dapat menurunkan jumlah gall pada akar padi dan tanaman padi
\end{abstract}


resisten terhadap $M$. graminicola. Ekstrak daun bayam duri dan beluntas dapat menekan jumlah J2 M. graminicola dalam tanah dan meningkatkan berat basah akar dan tinggi tanaman padi.

Kata Kunci: Ekstrak tumbuhan, Ketahanan sistemik terinduksi, Meloidogyne graminicola, Padi

\section{PENDAHULUAN}

Tanaman padi (Oryza sativa L.) merupakan salah satu tanaman serealia penting di dunia. Produksi padi di Indonesia pada tahun 2013 mencapai 71.279.709 ton, tetapi pada tahun 2014 produksinya menurun menjadi 70.846 .465 ton (BPS, 2015). Patogen tanaman seperti jamur, bakteri, virus, dan nematoda merupakan faktor pembatas utama pada budidaya tanaman padi. Nematoda bengkak akar (Meloidogyne graminicola Golden and Birchfiels) penyebarannya luas, dan sebagai patogen tular tanah penting yang dapat menurunkan produktivitas padi di Asia Tenggara (Padgham et al., 2004 dalam Pocharel, 2012). Nematoda ini telah dilaporkan terdapat di daerah pertanaman padi di Indonesia.

Di Yogyakarta populasi nematoda $M$. gramincola cukup tinggi, yaitu 3.548 ekor/g akar padi, bahkan di daerah tertentu mencapai 5.000 ekor/g akar padi (Mulyadi, 1997). Berdasarkan penelitian Bridge \& Page (1982) dalam Mulyadi (1997), populasi nematoda 4.000 ekor/tanaman padi mengakibatkan kerusakan 72\%. Kehilangan hasil padi yang disebabkan oleh $M$. graminicola berkisar antara 20\%-80\% di Asia Selatan dan Tenggara (Jaiswal et al., 2011 dalam Nurjayadi, 2015). Tanaman padi yang terserang oleh $M$. graminicola menjadi kerdil dan menguning, terbentuk gall pada akar dan tanaman kehilangan vigor (Yik \& Birchfield, 1979 dalam Singh et al., 2013).

Pengendalian nematoda parasit tanaman sangat sulit, dan strategi paling berhasil adalah penggunaan nematisida Metil bromida, Ethylene dibromide (EDB) dan Dibromochloropropane (DBCP), tetapi telah ditarik dari pasar karena mengakibatkan efek berbahaya pada manusia dan lingkungan (Oka et al., 2000b). Untuk mengurangi ketergantungan pada penggunaan nematisida secara kimia, perlu ada strategi baru untuk pengendalian nematoda, dan penelitian yang telah dilakukan difokuskan pada pengendalian secara biologi, aplikasi bahan organik dan inorganik, nematisida alami, dan induksi resistensi (Oka et al., 2000a).

Induksi resistensi tanaman dengan ekstrak tumbuhan adalah alternatif dalam pengendalian namatoda secara alami, efektif, dan aman. Tanaman memiliki mekanisme pertahanan endogenous (dari dalam) yang dapat diinduksi/dipicu untuk melawan respons terhadap serangan nematoda. Gen-gen pertahanan adalah gen-gen yang dapat diinduksi dan merangsang sinyal yang dibutuhkan untuk mengaktifkannya. Induksi mekanis pertahanan milik tanaman dengan aplikasi inducer (bahan penginduksi), merupakan strategi proteksi tanaman (Ramamoorthy et al., 2001).

Ketahanan tanaman diperoleh dengan meningkatkan aktifitas gen-gen pertahanan yang dipicu oleh bahan penginduksi dinamakan Ketahanan Sistemik Terinduksi (KST) (Kuch, 1987 dalam Hersanti, 2004). KST dapat diaktifkan oleh beberapa bahan penginduksi seperti kompos, mikroba antagonis, bahan kimia (Carolina, 2000 dalam Hersanti, 2004), dan ekstrak tanaman (Hersanti, 2004).

Hasil riset yang telah dilakukan menunjukkan bahwa bakteri endofit asal tanaman padi dapat digunakan sebagai bahan penginduksi untuk ketahanan tanaman padi terhadap $M$. graminicola. Aplikasi bakteri endofit dilakukan secara seed treatment (perlakuan benih), dan penyemprotan pada tanaman. Bakteri endofit dapat menekan jumlah gall pada akar tanaman padi dan meningkatkan pertumbuhan tanaman (Sunarto dkk., 2016). Aplikasi ekstrak daun eceng gondok, bayam duri, kirinyuh, dan beluntas yang disemprotkan pada tanaman padi efektif dapat menekan penyakit bengkak akar pada padi yang disebabkan oleh $M$. graminicola (Sunarto dkk., 2016). Saat ini terdapat peningkatan serangan $M$. graminicola pada padi, dan penelitian induksi resistensi pada tanaman padi terhadap M. graminicola belum banyak dilakukan, sehingga perlu dilakukan pengembangan penelitian tentang induksi sistemik resistensi pada tanaman padi dengan bermacam jenis ekstrak tumbuhan terhadap $M$. graminicola. Ekstrak tumbuhan diaplikasikan dengan cara: disemprotkan pada tanaman padi, seed treatment (perendaman benih) dan soil drench (penyiraman tanah) pada skala semi lapangan. Tujuan penelitian ini untuk mendapakan jenis ekstrak tumbuhan yang efektif sebagai bahan 
penginduksi ketahanan tanaman padi terhadap serangan nematoda $M$. graminicola.

\section{BAHAN DAN METODE}

Penelitian dilakukan di rumah kaca Departemen Hama dan Penyakit Tumbuhan, Fakultas Pertanian, Universitas Padjadjaran, Jatinangor, dan pelaksanaan mulai bulan Mei 2018 sampai Nopember 2018. Penelitian menggunakan metode percobaan dengan Rancangan Acak Kelompok (RAK) terdiri dari 6 perlakuan dan 4 ulangan. Perlakuan sebagai berikut: kontrol (tanpa ekstrak tanaman), ekstrak daun: kirinyuh $10 \mathrm{ml} /$ pot, beluntas $10 \mathrm{ml} /$ pot, eceng gondok $10 \mathrm{ml} /$ pot, bayam duri $10 \mathrm{ml} /$ pot, dan Karbofuran 2 g/pot. Data hasil penelitian dianalisis dengan analisis varians (uji F), dan untuk membedakan rata-rata perlakuan diuji dengan uji Jarak Berganda Duncan pada taraf nyata 5 $\%$.

\section{Persiapan Media Tanam dan Inokulum Nematoda Meloidogyne graminicola}

Tanah yang digunakan berasal dari lahan sawah di Kebun Percobaan Ciparanje, Jatinangor sebanyak $3 \mathrm{~L}$ per ember. Nematoda $M$. graminicola diambil dari lahan sawah di dekat IPB, Kec. Dramaga, Kab. Bogor, Jawa Barat. Nematoda diekstraksi dari akar tanaman padi yang terserang dan menunjukkan gejala gall. Bagian akar yang menunjukkan gejala gall dipotong (ukuran 0,5 - 1,0 $\mathrm{cm}$ ) lalu diproses dengan metode $\mathrm{NaOCl}$ (Collen, 1979 dalam van Bezooijen, 2006; Hussey \& Bakker, 1973). Bagian akar yang menunjukkan gejala gall dipotong, dimasukkan ke dalam Beaker glass dan ditambah $\mathrm{NaOCl}$ 0,5\% sampai seluruh bagian akar terendam, kemudian diaduk selama 3 menit lalu disaring dengan saringan diameter pori $750 \mu \mathrm{m}$. Hasil saringan disaring kembali dengan saringan bertingkat $50 \mu \mathrm{m}$, dan $35 \mu \mathrm{m}$. Nematoda pada saringan $50 \mu \mathrm{m}$ dan $35 \mu \mathrm{m}$ dibilas dengan air dan dikumpulkan dalam beaker glass. Kemudian dilakukan penghitungan jumlah nematoda per $\mathrm{ml}$ yang terdapat pada suspensi nematoda.

\section{Pembuatan Ekstrak Tumbuhan}

Tumbuhan kirinyuh, beluntas, eceng gondok dan bayam duri diambil dari Jatinangor dan Tanjungsari, Kabupaten Sumedang. Bagian tanaman yang digunakan adalah daun. Bagian tanaman dicuci bersih lalu ditimbang. Daun yang telah bersih dimasukkan ke dalam blender, ditambah aquades dengan perbandingan 1:1. Daun yang telah diblender diinkubasi selama 1 malam lalu disaring dengan kain muslin, kertas saring biasa dan kertas saring Whatmann no.1 secara berurutan. Ekstrak yang dihasilkan dimasukkan ke dalam botol kaca coklat dan disimpan di lemari es untuk digunakan selanjutnya.

\section{Aplikasi Agen Penginduksi dan Inokulasi Nematoda}

Aplikasi ekstrak tumbuhan dengan metode seed treatment (perendaman benih padi) dan soil drench (penyiraman pada tanah sekitar tanaman padi). Benih padi direndam dalam larutan ekstrak tumbuhan selama 24 jam dan diinkubasi selama 24 jam. Benih padi yang digunakan sebanyak 5 benih per ember. Benih padi disemai selama 15 hari di atas nampan yang telah diberi media sekam. Bibit padi kemudian dipindahtanam ke media tanah sawah di dalam ember dan dilakukan adaptasi selama 15 hari. Tanaman padi yang telah beradaptasi selama 15 hari, disiram dengan $10 \mathrm{ml}$ larutan ekstrak tumbuhan di tanah sekitar tanaman padi. Setelah 7 hari dari aplikasi ekstrak tumbuhan, tanaman padi diinokulasi dengan 300 J2 M. graminicola tiap perlakuan. Pada 35 hari setelah inokulasi, tanaman padi dilakukan pengamatan terhadap jumlah gall pada akar, jumlah J2 M. graminicola dalam $100 \mathrm{ml}$ tanah, berat basah bagian atas tanaman dan akar, serta tinggi tanaman padi.

\section{Pemeliharaan Tanaman}

Penyiraman dilakukan duahari sekali atau sesuai dengan kondisi tanah dan tanaman. Penyiangan gulma dilakukan seminggu sekali dengan menggunakan tangan.

\section{Data, Teknik Pengumpulan Data dan Sumber Data}

Data hasil pengamatan meliputi: jumlah gall pada akar tanaman padi, jumlah J2 Meloidogyne graminicola dalam $100 \mathrm{ml}$ tanah, berat basah bagian atas tanaman, berat basah akar, dan tinggi tanaman padi. Data jumlah gall pada akar dikumpulkan dengan cara $m$ enghitung jumlah gall yang terbentuk pada akar. Data jumlah J2 $M$. graminicola dalam $100 \mathrm{ml}$ tanah dikumpulkan dengan cara mengambil $100 \mathrm{ml}$ sampel tanah dari tiap perlakuan, kemudian tanah diekstraksi dengan metode corong Baermann untuk mendapatkan suspensi nematoda, selanjutnya dilakukan penghitungan jumlah nematoda. Data berat basah bagian atas tanaman, berat basah akar, dan tinggi tanaman padi dikumpulkan dengan cara tanaman dicabut, 
dipotong bagian pangkal akar, kemudian ditimbang berat basah bagian atas tanaman dan berat basah akar, serta diukur tinggi tanaman dari permukaan tanah sampai titik tumbuh tanaman padi. Data diperoleh pada saat 35 hari setelah tanaman padi diinokulasi dengan nematoda.

\section{Pengambilan atau Pemilihan Sampel}

Pengamatan dilakukan pada 35 hari setelah inokulasi nematoda terhadap:

1. Jumlah gall pada akar tanaman padi

Tanaman padi dicabut kemudian dihitung jumlah gall yang terbentuk pada akar dengan menggunakan hand counter.

2. Jumlah Juvenil tingkat kedua (J2) Meloidogyne graminicola dalam $100 \mathrm{ml}$ tanah

Perhitungan jumlah J2 $M$. graminicola dilakukan dengan cara mengambil sampel tanah sebanyak $100 \mathrm{ml}$ tanah per perlakuan di sekitar perakaran tanaman padi, kemudian tanah diekstraksi dengan metode corong Baermann dan diinkubasi selama 24 jam. Jumlah J2 dihitung dengan menggunakan mikroskop binokuler.

3. Berat basah bagian atas tanaman, berat basah akar, dan tinggi tanaman

Tanaman padi dicabut dengan hati-hati dan akar dicuci sampai bersih. Tanaman padi dipotong pada bagian pangkal batang, bagian akar ditimbang untuk mendapatkan berat basah akar, dan bagian atas tanaman ditimbang untuk mendapatkan berat basah bagian atas tanaman. Tinggi tanaman diukur dari pangkal batang sampai titik tumbuh tanaman.

\section{Pengolahan dan Analisis Data}

Data hasil pengamatan dianalisis dengan analisis varians (uji F), dan untuk mengetahui perbedaan di antara rata-rata perlakuan, dilakukan pengujian dengan Uji Jarak Berganda Duncan pada taraf nyata 5\%. Penilaian tingkat ketahanan tanaman ditentukan berdasarkan indeks gall dan faktor reproduksi. Penentuan indeks gall menurut Taylor \& Sasser (1978) dalam Sasser et al. (1984) sebagai berikut: Indeks gall 0 (Tanpa gall), 1 (1-2 gall), 2 (3-10 gall), 3 (11-30 gall), 4 (31-100 gall, 5 (>100 gall).

Menurut Hadisoeganda \& Sasser (1982) dalam Sasser et al. (1984), hubungan antara indeks gall dengan tingkat ketahanan sebagai berikut: Indeks gall 0-1 (Sangat resisten), 1,1 - 3,0 (Resisten), 3,1 - 3,5 (Moderat resisten), 3,6 - 4,0 (Agak tahan), 4,1- 5,0 (Rentan). Faktor reproduksi menurut Canto-
Saenz (1985) dalam Sasser et al. (1984) adalah perbandingan jumlah populasi nematoda akhir dengan populasi nematoda awal menggunakan rumus:

\section{$\mathrm{R}=\mathrm{Pf} / \mathrm{Pi}$}

$\mathrm{R}=$ Faktor reproduksi, $\mathrm{Pf}=$ populasi akhir, $\mathrm{Pi}=$ populasi awal

$\mathrm{R}=0$ (tanaman tahan), $\mathrm{R}<1$ (ketahanan sedang), $\mathrm{R}>1$ (rentan)

\section{HASIL DAN PEMBAHASAN}

\section{Jumlah Gall pada Akar Tanaman Padi}

Aplikasi ekstrak daun tanaman berpengaruh terhadap jumlah gall pada akar tanaman padi (Tabel 1). Jumlah gall terendah terdapat pada aplikasi ekstrak daun bayam duri (2,00 gall), diikuti dengan ekstrak daun beluntas (3,25 gall) yang tidak berbeda nyata dengan jumlah gall pada ekstrak daun kirinyuh, eceng gondok dan karbofuran, tetapi berbeda nyata dengan jumlah gall pada kontrol. Hal ini menunjukkan bahwa ekstrak daun bayam duri, daun beluntas, kirinyuh, dan eceng gondok dapat mempengaruhi penetrasi nematoda $M$. graminicola ke area perakaran tanaman padi. Ekstrak daun bayam duri, daun beluntas, kirinyuh, dan eceng gondok memiliki kemampuan menurunkan penyakit bengkak akar dan dapat digunakan secara efektif untuk induksi resistensi terhadap nematoda bengkak akar ( $M$. graminicola) pada tanaman padi. Aplikasi ekstrak daun tersebut pada tanaman padi mengakibatkan induksi resistensi sistemik ditunjukkan dengan penurunan jumlah gall pada akar tanaman padi.

Tabel 1. Rata-rata jumlah gall dan indeks gall pada akar tanaman padi pada 35 hari setelah inokulasi nematoda

\begin{tabular}{lcc}
\hline \multicolumn{1}{c}{ Perlakuan } & $\begin{array}{c}\text { Jumlah gall } \\
\text { pada akar }\end{array}$ & $\begin{array}{c}\text { Indeks } \\
\text { gall }\end{array}$ \\
\hline A. Kontrol (tanpa ekstrak & $33,50 \mathrm{~b}$ & 5 \\
tanaman) & & \\
B. Ekstrak daun kirinyuh & $4,25 \mathrm{a}$ & 2 \\
C. Ekstrak daun beluntas & $3,25 \mathrm{a}$ & 2 \\
D. Ekstrak daun eceng gondok & $3,75 \mathrm{a}$ & 2 \\
E. Ekstrak daun bayam duri & $2,00 \mathrm{a}$ & 1 \\
F. Karbofuran & $4,25 \mathrm{a}$ & 2 \\
\hline
\end{tabular}
Keterangan: Nilai yang diikuti dengan huruf yang sama menunjukkan tidak berbeda nyata menurut uji Duncan pada taraf nyata 5\%. Indeks Gall: $0-1=$ Sangat resisten; $1,1-3=$ Resisten; 3,1 $-3,5=$ Moderat resisten; 3,6 $-4=$ Agak tahan; 4,1 $-5=$ Rentan 
Berdasarkan penelitian yang dilakukan oleh Rorong dan Suryanto (2010), bagian daun eceng gondok mengandung fenolik, flavonoid, dan tanin yang lebih tinggi daripada bagian batang dan akar, sedangkan berdasarkan penelitian Sulistyaningsih (2016), daun bayam duri mengandung senyawa alkaloid dan saponin. Daun beluntas, berdasarkan penelitian Widyawati dkk. (2013), mengandung tanin, sterol, flavonoid, dan fenol hidrokuinon. Daun kirinyuh menyandung senyawa utama seperti tanin, fenol, flavonoid, saponin, dan steroid (Eriadi, 2016). Saponin bersifat nematisidal yang dapat menghambat akumulasi kolesterol dalam telur dan/atau larva (Ibrahim \& Srour, 2013). Fenolik, terpenoid, flavonoid, dan alkaloid memiliki hormon juvenil sehingga dapat berpengaruh pada perkembangan serangga (Elimam et at, 2009).

Aplikasi ekstrak daun bayam duri dengan cara perendaman benih padi pada ekstrak daun bayam duri dan penyiraman ekstrak daun bayam duri pada tanah sekitar perakaran tanaman padi menghasilkan indeks gall $=1$, hal ini menunjukkan bahwa tanaman padi sangat resisten terhadap serangan nematoda bengkak akar (Meloidogyne graminicola). Aplikasi ekstrak daun kirinyuh, beluntas, eceng gondok dan karbofuran, menghasilkan indeks gall $=2$, hal ini menunjukkan bahwa tanaman resisten terhadap $M$. graminicola, sedangkan pada kontrol menghasilkan indeks gall = 5 yang menunjukkan bahwa tanaman padi rentan terhadap M. graminicola.

\section{Jumlah Juvenil Tingkat Kedua (J2) M. graminicola dalam $100 \mathrm{ml}$ Tanah}

Aplikasi ekstrak tanaman berpengaruh terhadap jumlah J2 M. graminicola dalam $100 \mathrm{ml}$ tanah (Tabel 2). Berdasarkan Tabel 2, jumlah J2 $M$. graminicola terendah terdapat pada aplikasi ekstrak daun bayam duri (1,75 ekor), diikuti dengan ekstrak daun beluntas (2,75 ekor), dan karbofuran (2,75 ekor) yang berbeda nyata dengan kontrol, tetapi tidak berbeda nyata dengan jumlah J2 pada aplikasi ekstrak daun kirinyuh dan eceng gondok. Hal ini menunjukkan bahwa ekstrak daun bayam duri dan daun beluntas dapat menekan populasi nematoda $M$. graminicola dalam tanah. Berdasarkan penelitian Sulistyaningsih (2016), daun bayam duri mengandung senyawa alkaloid dan saponin. Daun beluntas, berdasarkan penelitian Widyawati dkk (2013), mengandung tanin, sterol, flavonoid, dan fenol hidrokuinon. Aplikasi ekstrak daun bayam duri menghasilkan faktor reproduksi nematoda $(\mathrm{R}=$ $0,175)$, sedangkan ekstrak daun beluntas $(R=0,275)$, hal ini menunjukkan bahwa tanaman padi memiliki ketahanan sedang terhadap serangan nematoda bengkak akar (M. graminicola).

Tabel 2. Rata-rata jumlah juvenil tingkat kedua (J2) M. graminicola dalam $100 \mathrm{ml}$ tanah pada 35 hari setelah inokulasi nematoda

\begin{tabular}{|c|c|c|}
\hline Perlakuan & Jumlah J2 M. graminicola (ekor) & Faktor Reproduksi (R) \\
\hline A. Kontrol & $8,25 \mathrm{~b}$ & 0,825 \\
\hline B. Ekstrak daun kirinyuh & $3,50 \mathrm{ab}$ & 0,350 \\
\hline C. Ekstrak daun beluntas & $2,75 \mathrm{a}$ & 0,275 \\
\hline D. Ekstrak daun eceng gondok & $5,00 \mathrm{ab}$ & 0,500 \\
\hline E. Ekstrak daun bayam duri & 1,75 a & 0,175 \\
\hline F. Karbofuran & $2,75 \mathrm{a}$ & 0,275 \\
\hline
\end{tabular}

Keterangan: Nilai yang diikuti dengan huruf yang sama menunjukkan tidak berbeda nyata menurut uji Duncan pada taraf nyata 5\%. Faktor Reproduksi (R): $\mathrm{R}=0$ (Tanaman tahan), $\mathrm{R} \leq 1$ (Ketahanan tanaman sedang), $\mathrm{R}>1$ (Tanaman rentan)

Berat Basah Bagian Atas Tanaman, Berat Basah Akar, dan Tinggi Tanaman Padi

Aplikasi ekstrak tanaman berpengaruh terhadap berat basah akar, dan tinggi tanaman padi, tetapi tidak berpengaruh terhadap berat basah bagian atas tanaman padi (Tabel 3). Berdasarkan Tabel 3, aplikasi ekstrak daun tanaman cenderung meningkatkan berat basah bagaian atas tanaman padi dibandingkan dengan kontrol. Berat basah bagian atas tanaman tertinggi terdapat pada aplikasi ekstrak daun kirinyuh (76,25 g), diikuti dengan ekstrak daun eceng gondok (73,75 g), ekstrak daun bayam duri (73,75 g) dan karbofuran (73,75 g). Hal ini menunjukkan bahwa ekstrak daun kirinyuh, eceng gondok, bayam duri dapat menghambat nematoda untuk mengambil nutrisi pada tanaman padi.

Daun kirinyuh menyandung senyawa utama seperti tanin, fenol, flavonoid, saponin, dan steroid (Eriadi, 2016). Saponin bersifat nematisidal 
yang dapat menghambat akumulasi kolesterol dalam telur dan/atau larva (Ibrahim \& Srour, 2013). Fenolik, terpenoid, flavonoid, dan alkaloid memiliki hormon juvenil sehingga dapat berpengaruh pada perkembangan serangga (Elimam et al., 2009). Berdasarkan penelitian yang dilakukan oleh Rorong dan Suryanto (2010), bagian daun eceng gondok mengandung fenolik, flavonoid, dan tanin yang lebih tinggi daripada bagian batang dan akar, sedangkan berdasarkan penelitian Sulistyaningsih (2016), daun bayam duri mengandung senyawa alkaloid dan saponin.

Tabel 3. Rata-rata berat basah bagian atas tanaman, berat basah akar, dan tinggi tanaman padi pada 35 hari setelah inokulasi nematoda

\begin{tabular}{lccc}
\hline \multicolumn{1}{c}{ Perlakuan } & $\begin{array}{c}\text { Berat basah bagian } \\
\text { atas tanaman }(\mathrm{g})\end{array}$ & $\begin{array}{c}\text { Berat basah akar } \\
(\mathrm{g})\end{array}$ & $\begin{array}{c}\text { Tinggi tanaman } \\
(\mathrm{cm})\end{array}$ \\
\hline A. Kontrol (tanpa ekstrak tanaman) & $67,50 \mathrm{a}$ & $28,75 \mathrm{c}$ & $72,50 \mathrm{~b}$ \\
B. Ekstrak daun kirinyuh & $76,25 \mathrm{a}$ & $40,25 \mathrm{~b}$ & $78,00 \mathrm{a}$ \\
C. Ekstrak daun beluntas & $70,00 \mathrm{a}$ & $43,87 \mathrm{ab}$ & $77,87 \mathrm{a}$ \\
D. Ekstrak daun eceng gondok & $73,75 \mathrm{a}$ & $40,12 \mathrm{~b}$ & $77,62 \mathrm{a}$ \\
E. Ekstrak daun bayam duri & $73,75 \mathrm{a}$ & $46,62 \mathrm{a}$ & $79,12 \mathrm{a}$ \\
F. Karbofuran & $73,75 \mathrm{a}$ & $34,12 \mathrm{c}$ & $75,62 \mathrm{a}$ \\
\hline
\end{tabular}

Keterangan: Nilai yang diikuti dengan huruf yang sama dalam kolom yang sama menunjukkan tidak berbeda nyata menurut uji Duncan pada taraf nyata $5 \%$

Berat basah akar tertinggi diperoleh pada aplikasi ekstrak daun bayam duri (46,62 g), yang berbeda nyata dengan berat basah akar pada kontrol, ekstrak daun kirinyuh, eceng gondok, dan karbofuran. Hal ini menunjukkan bahwa ekstrak daun bayam duri dapat menghambat nematoda untuk mengambil nutrisi pada tanaman padi. Berdasarkan penelitian Sulistyaningsih (2016), daun bayam duri mengandung senyawa alkaloid dan saponin. Tinggi tanaman padi terbaik terdapat pada aplikasi ekstrak daun bayam duri $(79,12 \mathrm{~cm})$, kirinyuh $(78,00 \mathrm{~cm})$, beluntas $(77,87 \mathrm{~cm})$, daun eceng gondok $(77,62 \mathrm{~cm})$ yang tidak berbeda nyata dengan tinggi tanaman pada kontrol $(72,50 \mathrm{~cm})$.

Berdasarkan penelitian Sulistyaningsih (2016), daun bayam duri mengandung senyawa alkaloid dan saponin. Daun kirinyuh menyandung senyawa utama seperti tanin, fenol, flavonoid, saponin, dan steroid (Eriadi, 2016). Daun beluntas mengandung tanin, sterol, flavonoid, dan fenol hidrokuinon (Widyawati dkk., 2013). Berdasarkan penelitian yang dilakukan oleh Rorong dan Suryanto (2010), bagian daun eceng gondok mengandung fenolik, flavonoid, dan tanin yang lebih tinggi daripada bagian batang dan akar.

\section{SIMPULAN DAN SARAN}

\section{Simpulan}

Berdasarkan hasil dan pembahasan dapat disimpulkan sebagai berikut:
1. Ekstrak daun tumbuhan berpengaruh dalam menekan serangan nematoda bengkak akar (Meloidogyne graminicola) pada tanaman padi.

2. Aplikasi ekstrak daun tanaman bayam duri dan beluntas dengan metode seed treatment (perendaman benih padi) dan soil drench (penyiraman pada tanah sekitar tanaman padi) dapat menurunkan jumlah gall pada akar padi dan tanaman padi resisten terhadap $M$. graminicola. Eekstrak daun bayam duri dan beluntas dapat menekan jumlah J2 $M$. graminicola dalam tanah dan meningkatkan berat basah akar dan tinggi tanaman padi.

\section{Saran}

Ekstrak daun tanaman bayam duri dan beluntas dapat digunakan sebagai bahan penginduksi ketahanan tanaman padi terhadap serangan nematoda bengkak akar (Meloidogyne graminicola).

\section{UCAPAN TERIMA KASIH}

Penelitian ini terlaksana berkat kerjasama dengan Rektor Universitas Padjadjaran. Kami mengucapkan terima kasih kepada Rektor Unpad yang telah memberi Dana Hibah Internal Unpad Tahun 2018, melaui Riset Kompetensi Dosen Unpad.

\section{DAFTAR PUSTAKA}

Badan Pusat Statistik. 2015. Tabel Dinamis Produksi, Produktivitas, dan Luas Panen Padi di 
Indonesia. Tersedia online pada http://www.bps.go.id/. Diakses pada 15 Juli 2015.

Elimam, AM, KH Elmalik, and FS Ali. 2009. Larvicidal, adult emergence inhibition and oviposition deterrent effects of foliage extract from Ricinus communis L. against Anopheles arabiensis and Culex quinquefasciatus in Sudan. Tropical Biomedicine. 26(2): 130-139.

Eriadi, A, A Helmi, dan Nirwanto. 2016. Uji toksisitas akut ekstrak etanol daun kirinyuh (Chromolaenodorata (L) R.M. King \& H. Rob) pada mencit putih jantan. Jurnal Farmasi Higea. 8(2): 122-132.

Hersanti. 2004. Penujian Keefektifan Ekstrak Daun Bunga Pukul Empat (Mirabilis jalapa) dalam Menginduksi Ketahanan Sistemik Tanaman Cabai terhadap Serangan Cucumber Mosaic Virus (CMV). Pustaka Unpad.

Hussey, RS, and KR Barker. 1973. A Comparison of methods of collecting inocula of Meloidogyne spp. including a new technique. Plant Disease Reporter. 57: 10251028.

Ibrahim, MAR, and HAM Srour. 2013. Saponins suppress nematode cholesterol biosynthesis and inhibit root knot nematode development in tomato seedlings. Nat Prod Chem Res 2: 123.

Mulyadi, 1997. Pengaruh populasi nematoda bengkak akar (Meloidogyne graminicola) terhadap pertumbuhan dan hasil padi. Jurnal Perlindungan Tanaman Indonesia. 3(1): 17-22.

Nurjayadi, MY, A Munif, dan G Suastika. 2015. Identifikasi nematoda puru akar, Meloidogyne graminicola, pada tanaman padi di Jawa Barat. Jurnal Fitopatologi Indonesia. 11(4): 113-120.

Oka, Y, H Koltai, MB Eyal, M Mor, E Sharon, I Chet, and Y Spiegel. 2000a. New strategies for the control of plant parasitic nematodes. Pest management Science. 56: 983-988.

Oka, Y, S Nacar, E Putievsky, U Ravid, Z Yaniv, and Y Spegel. 2000b. Nematicidal activity of essential oils and their componens against the root-knot nematode. Journal of Phytopathology. 90: 710-715.

Pocharel, RR, IM Duxbury, and G Abawai. 2012. Evaluation of protocol for Assesing the reaction of Rice and wheat germplasm to infection by Meloidogyne graminicola. J. Nematol. 44(3): 274-283.

Ramamoorthy, V, B Viswanathan, I Raguchandar, T Prakasham, and B Samiyappan. 2001. Induction of systemic resistance by plant growth rhizobacteria in crop plants against pest and diseases. Crop protection. 20: 1-11.

Rorong, JA, dan S Edi. 2010. Analisis fitokimia enceng gondok (Eichhornia crassipes) dan efeknya sebagai agen photoreduksi $\mathrm{Fe}^{3+}$. Chem. Prog. 3(1): 33-41.

Sasser, JN, CC Carter, and KM Hartman. 1984. Standardization of Host Suitability Studies and Reporting of Resistance to Root-Knot Nematodes. Crop Nematodes Research \& Control Project (CNRCP). Raleigh, North Carolina.

Singh, A, RK Jaiswal, S Maurya, and UP Singh. 2013. Analysis of phenolic and indole acetic acids in Meloidogyne graminicola infected rice plants (Oryza sativa L.). International Journal of Advance Research. 1(6): 71-76.

Sulistyaningsih, Rr., Firmansyah, dan T Ami. 2016. Uji aktivitas ekstrak etanol bayam duri (Amaranthus spinosus) terhadap bakteri Staphylococcus aureus dan Pseudomonas aeruginosa dengan metode difusi agar. Farmaka. 14(1): 93-101.

Sunarto, T, T Suganda, and FN Fazrina. 2016. Pengujian Bakteri Endofit untuk Meningkatkan Ketahanan Tanaman Padi terhadap Nematoda Bengkak Akar (Meloidogyne graminicola). Penelitian ALG. Universitas Padjadjaran.

Van Bezooijen, J. 2006. Methods and Techniques for Nematology: Revised version 2006. Wageningen.

Widyawati, PS, W Hanny, SH Peni, dan S Dondin. 2013. Aktivitas antioksidan berbagai fraksi dan ekstrak metanolik daun beluntas (Pluchea indica Less). AGRITECH. 32(3): 249-257. 